\title{
Experimental study of slow sand filtration for the treatment of various wastewaters in tropical environment
}

\author{
Cheikh DIOP ${ }^{1,2^{*}}$, Maïmouna D. DIARRA ${ }^{1}$, El Hadji Mamadou SONKO ${ }^{1,4}$, \\ Maïmouna TINE ${ }^{1}$, François MATTY ${ }^{1}$, Anicet Da SILVA ${ }^{3}$, Ibahima Papa Mbor DIONE ${ }^{5}$ \\ and Alphonse TINE ${ }^{2}$ \\ ${ }^{I}$ Institut des Sciences de l'Environnement, Faculté des Sciences et Techniques, Université Cheikh Anta Diop de \\ Dakar. BP 5005 Dakar, Fann, Sénégal. \\ ${ }^{2}$ Laboratoire de Photochimie et d'Analyses, Département de Chimie, Faculté des Sciences et Techniques, \\ Université Cheikh Anta Diop de Dakar. BP 5005 Dakar, Fann, Sénégal. \\ ${ }^{3}$ Département de Physiques, Faculté des Sciences et Techniques, Université Cheikh Anta Diop, \\ Dakar, BP 5005 Dakar, Fann, Sénégal. \\ ${ }^{4}$ Eawag; Swiss Federal Institute of Aquatic Science and Technology Sandec; Department of Water and \\ Sanitation in Developing Countries Ueberlandstrasse 133, 8600 Duebendorf, Switzerland \\ ${ }^{5}$ Office National de l'Assainissement du Sénégal, Cité TP SOM, n॰ 4, Hann, BP 13428, Dakar, Sénégal. \\ *Auteur correspondant ; Email : namorydiop@yahoo.fr; Tel : (221) 77.501.42.61
}

\begin{abstract}
Wastewater treatment by slow sand filtration is a biological process which consists in filtering wastewater through a porous media. The objective of this study was to evaluate the performances of this biotechnology under tropical climate. Three sand filters were monitored at ONAS (Cambérène wastewater treatment plant in Dakar, Senegal). The filters were built with local materials, and were constituted with a feeding tank of approximately 180 litters, a column (two meters high and 30-25 cm diameter). The filters were filled with sand $(75 \mathrm{~cm})$, gravel $(25 \mathrm{~cm})$ and wastewater $(90 \mathrm{~cm})$. The results showed that with sand of $\mathrm{d}_{10}$ equal to $0.58 \mathrm{~mm}$ and flow rate of $0.05 \mathrm{~m} / \mathrm{h}$, the filtration cycle was relatively long for the first run with pretreated wastewater. At the level of the primary settling tank, with flow a rate of $0.08 \mathrm{~m} / \mathrm{h}$, the removal rates were about $12.75 \%, 16.31 \%, 12.92 \%, 5.45 \%, 7.09 \%$ and $10.50 \%$ for TSS, COD, $\mathrm{BOD}_{5}$, nitrogen phosphorus and faecal coliforms respectively. At the level of the clarifier, with a filtration of $0.15 \mathrm{~m} / \mathrm{h}$, the removals were $1.4 \%$ for TSS, $1.84 \%$ for COD, $1.09 \%$ for $\mathrm{BOD}_{5} 11.38 \%$ for nitrogen, $5.18 \%$ for phosphorus and $1.74 \%$ of faecal coliforms.

(C) 2014 International Formulae Group. All rights reserved.
\end{abstract}

Keywords: Flow rate; filtration cycle, removal; sand filtration; tropical climate, wastewater.

\section{INTRODUCTION}

The increasing use of raw or treated wastewater for various purposes throughout the world contributed to the development of guidelines to protect the environment and public health (WHO, 2006; Abdel Ghaffar, 2007; RSA, 2012; Bastian, 2013). In agriculture, the benefits is not only in the preservation of the environment and resource, but also in the nature of wastewater containing 
nutrients (nitrogen, phosphorus and potassium, etc.) that are beneficial for crops, and can significantly increase the production (Aomar et al., 2002; Shetty, 2004). In Senegal, the field of wastewater had drawn special attention from the authorities; because the lack of adequate systems for wastewater treatment can cause serious environmental dysfunctions. According to the Director of Cambérène WWTP, only $37 \%$ wastewater are collected by the sewerage system. Because of problems related to water availability and competing uses, the reuse of raw wastewater in gardening has become a widespread practice in peri-urban areas in Senegal, as in many countries in Sahelian countries in Africa (Niang and Redwood, 2002). Then, wastewater treatment appears essential to reduce health risks associated with raw wastewater; also it participates in the improvement of people's life and contributes to environmental protection. Therefore, this study was aimed at evaluating the performances of sand filter biotechnology under tropical climate for agricultural water reuse.

\section{MATERIALS AND METHODS}

Experimental design, feeding and sampling systems

The pilot plans (Figure 1) were built based on the literature (Adin, et al., 1998; Dash, et al. 2012; Mbaye and al., 2012; Adeniran and Akanmu 2013; Amin and Mohamed, 2014). Thus, PVC pipes of $2 \mathrm{~m}$ high and $30-25 \mathrm{~cm}$ diameter were used as sand filters. The column was filled from bottom to top with $25 \mathrm{~cm}$ of fine and coarse gravel, $75 \mathrm{~cm}$ of coarse sand and $90 \mathrm{~cm}$ of wastewater. The sand has $d_{10}$ of $0.58 \mathrm{~cm}$ and a uniformity coefficient of 1.5 . Flow rates were about 0.05 to $0.15 \mathrm{~m} / \mathrm{h}$. Three barrels of 180 liters each were placed $1.5 \mathrm{~m}$ above each filter. They were placed close to the preliminary treatment system and the settling tanks of Camberene WWTP respectively. The influents were pumped from the preliminary treatment system or settling tanks to the barrels and arrived in the filter column $(90 \mathrm{~cm}$ of wastewater) through a valve actuated by a float disposed laterally on the bottom of the latter. The effluents flowed by gravity into the filters. Sampling valves are drilled into the filters above the sand surface, in the water body (level 1), and at $5 \mathrm{~cm}$ (level 2), $15 \mathrm{~cm}$ (level 3), $35 \mathrm{~cm}$ (level 4), $55 \mathrm{~cm}$ (level 5), 95 $\mathrm{cm}$ (level 6) in the filter column under the sand surface. The valves were connected to piezometers to measure the head loss. Results of filtered wastewater at different levels are here presented in this paper.

Four experiments were conducted. In the first experiments 1 and 2, pretreated wastewater (degritted, defatted) was settled for 12 days (Experiment 1) or 1.5 days (Experiment 2) prior to filtration. Experiments 3 and 4 are related to the filtration of wastewaters from primary and secondary (clarifier) settling tanks respectively.

\section{Sampling and analysis}

Samples were collected in one liter bottles, kept in a cooler with ice and transported to the lab within one hour for analysis. The influent sludge and the treated wastewater were analyzed for TSS, COD, BOD5, nitrogen phosphorus and faecal coliforms in the laboratory at the Camberene wastewater treatment plant following specific methods described in Standard Methods (Eaton et al.; 2005).

The head losses were measured daily from piezometers by direct reading of the variations in height of the water level in the pipes. Dissolved oxygen was measured directly with Oxytops WWT apparatus. 


\section{RESULTS}

Performances of settling prior to sand filtration

After twelve days of settling, the decanted wastewater gave high removal rates of about $98 \%, 89 \%$ and $95 \%$, with averages initial concentrations of $602 \mathrm{mg} / \mathrm{l}, 1653 \mathrm{mg}$ $\mathrm{O}_{2} / 1$ and $1010 \mathrm{mg} \mathrm{O}_{2} / \mathrm{l}$, for TSS, COD and $\mathrm{BOD}_{5}$ respectively. After filtration, the concentrations at the outlet were between 28 and $2 \mathrm{mg} / \mathrm{l}$, with an average rate of $6 \mathrm{mg} / \mathrm{l}$, showing a removal efficiency of $54 \%$ for TSS. COD content was between 164 to $19 \mathrm{mg} \mathrm{O} / \mathrm{l}$, with an average of $104 \mathrm{mg} \mathrm{O}_{2} / 1$ and a removal efficiency of $40 \%$.

In the second part of this study, the decantation time was reduced to 1.5 days while maintaining the filtration rate (Table 1).

The percentage reductions following the filtration were about $66,73,89$ and $91 \%$ on average, for TSS, COD, $\mathrm{BOD}_{5}$ and TKN, respectively.

\section{Evaluation of the filtration efficiency Variation of head losses}

The head loss profile across the sand bed was measured by piezometers as illustrated in Figure 2. The head losses at the different sampling points were established as compared to the head loss near the sand surface. The head losses variation for the level 2 , situated $5 \mathrm{~cm}$ below the sand surface evolved exponentially from the beginning to the end of the filtration with many fluctuations as mentioned in the literature (Adin and Rebhun, 1977; Channing et al., 2007).

Changes in oxygen content during the filtration

Changes in oxygen content in the filter close to primary settling tank are mentioned in Figure 3. This figure shows that the variation of the oxygen content in the column of the filter was highly variable. The evolution and the concentration of the oxygen content in the water body were not very different to that in the sand column (depths of $21.5 \mathrm{~cm}$ and 100 $\mathrm{cm})$.

The concentration of dissolved oxygen contents in the filter located near the clarifier was also highly variable as shown in Figure 4. However, the amount of oxygen was higher and greater than $1 \mathrm{mg} \mathrm{O}_{2} / 1$ in most of the time of the filtration monitoring.

Results of the filtration of the effluent of the primary settling tank and the clarifier (Experiment 3)

At the level of the primary settling tank

The results of the removal rate efficiency of the filtered wastewater sampled at the level of the primary settling tank are here presented: 63.9, 46.88, 53.23, 22.43, 8.07 and $56.19 \%$ for TSS, COD, $\mathrm{BOD}_{5}$, TKN, TP and faecal coliforms with an average content of: $46, \quad 362,123,131,18.56 \mathrm{mg} / \mathrm{l}$ and 1015.2.103 CFU/100 $\mathrm{ml}$ for TSS, COD, $\mathrm{BOD}_{5}, \mathrm{TKN}, \mathrm{TP}$ and faecal coliforms, respectively.

The filter placed close to the secondary settling tank filter (Experiment IV)

The results shown by sand filtration of the clarified wastewater are represented in Table 3. The filtration of clarified wastewater led to removal rates of about $74.54,34.84$, 20.01, 21.13, 22 and $77.2 \%$ on average for TSS, COD, BOD5, TKN, TP and faecal coliforms. These removal rates lower than those in Experiment 1 and Experiment 2 are due to the lower pollutants contents of the clarified wastewater. Indeed, initial clarified wastewater quality characteristics expressed in $\mathrm{mg} / \mathrm{l}$ were: $17.17,116.81,33.33,119.46$, 7.9 , on average for respectively TSS, COD, BOD5, TKN and TP. The average total coliforms content was $249.10^{3}$ CFU/100 ml. 


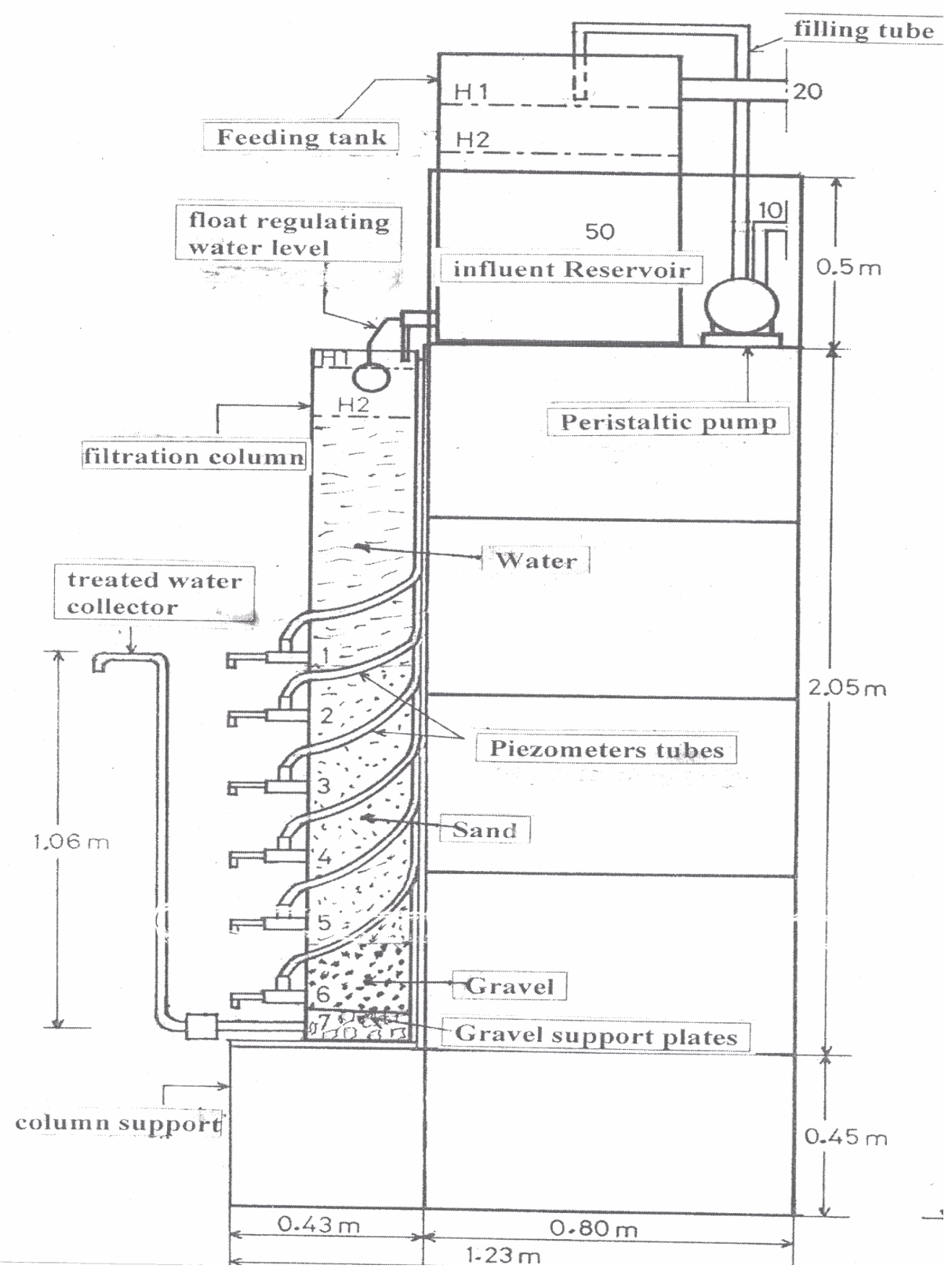

Figure 1: Schematic of pilot plan used in slow sand filtration. 


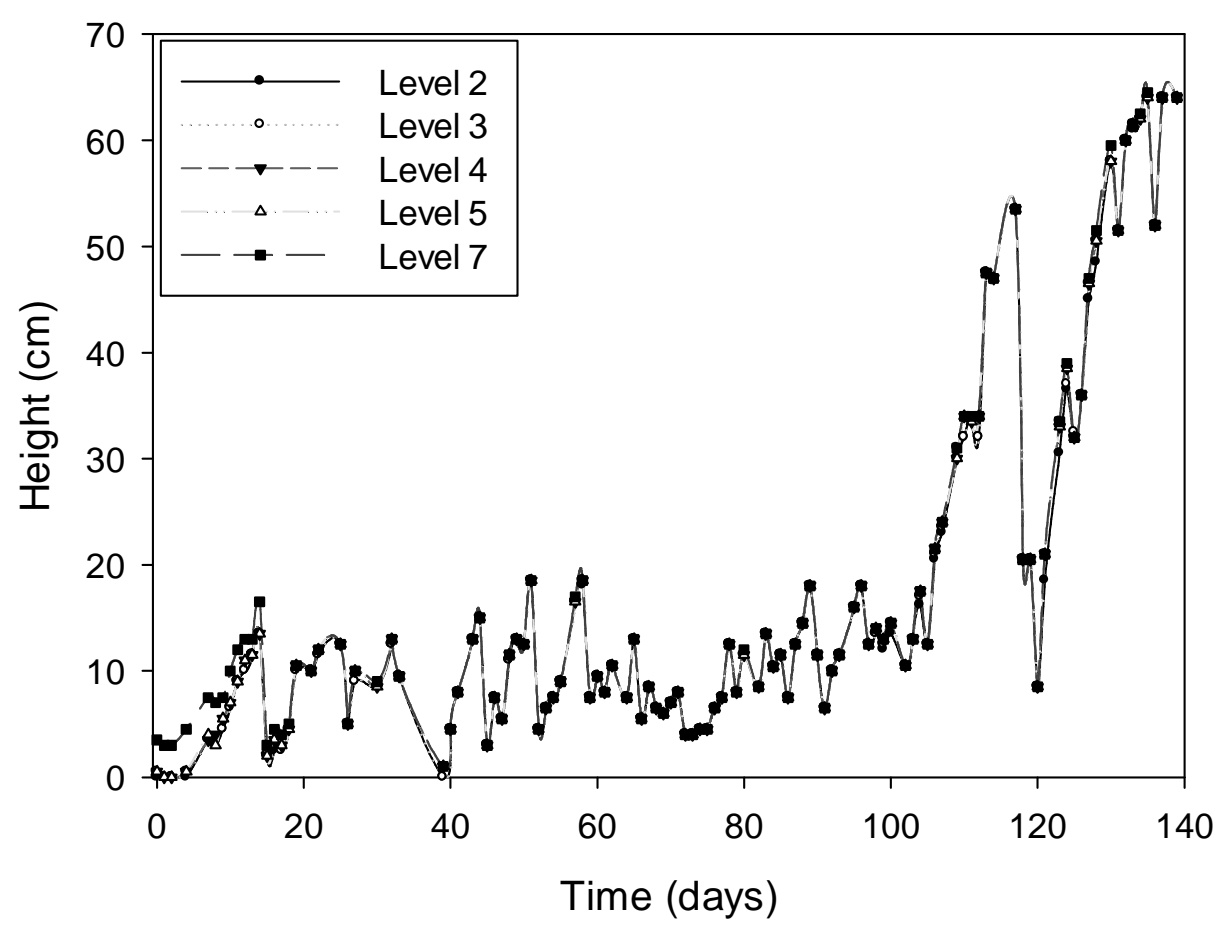

Figure 2: Evolution of head losses at different levels of the column.

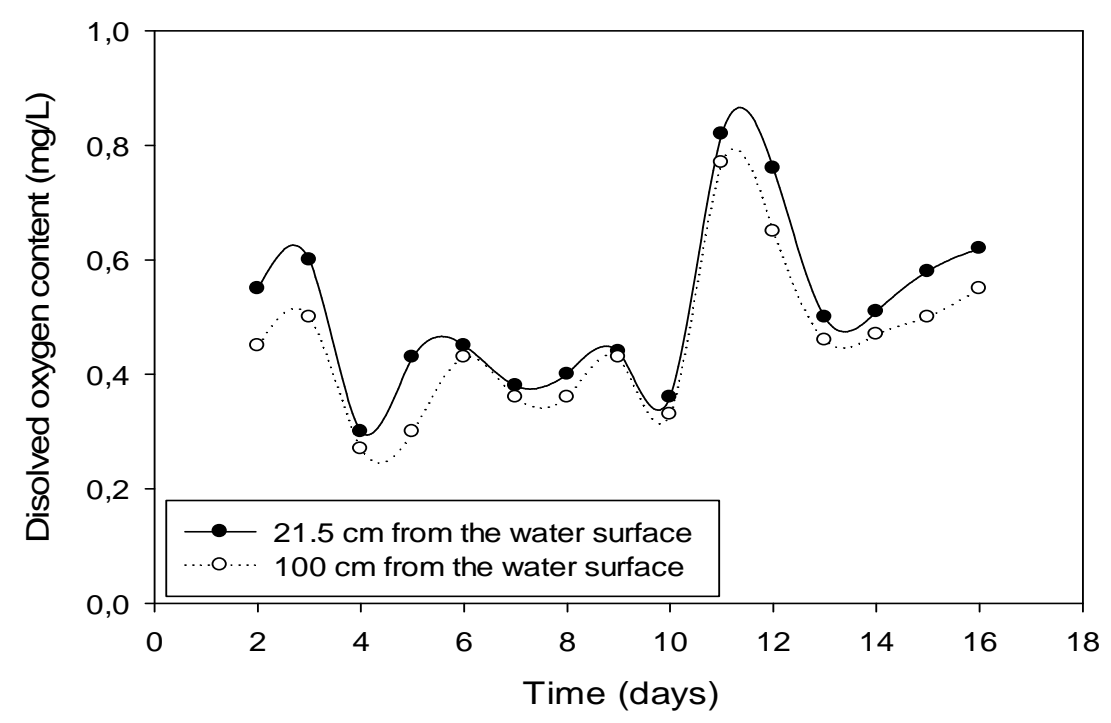

Figure 3: Changes in oxygen content in the filter close to the primary settling tank. 


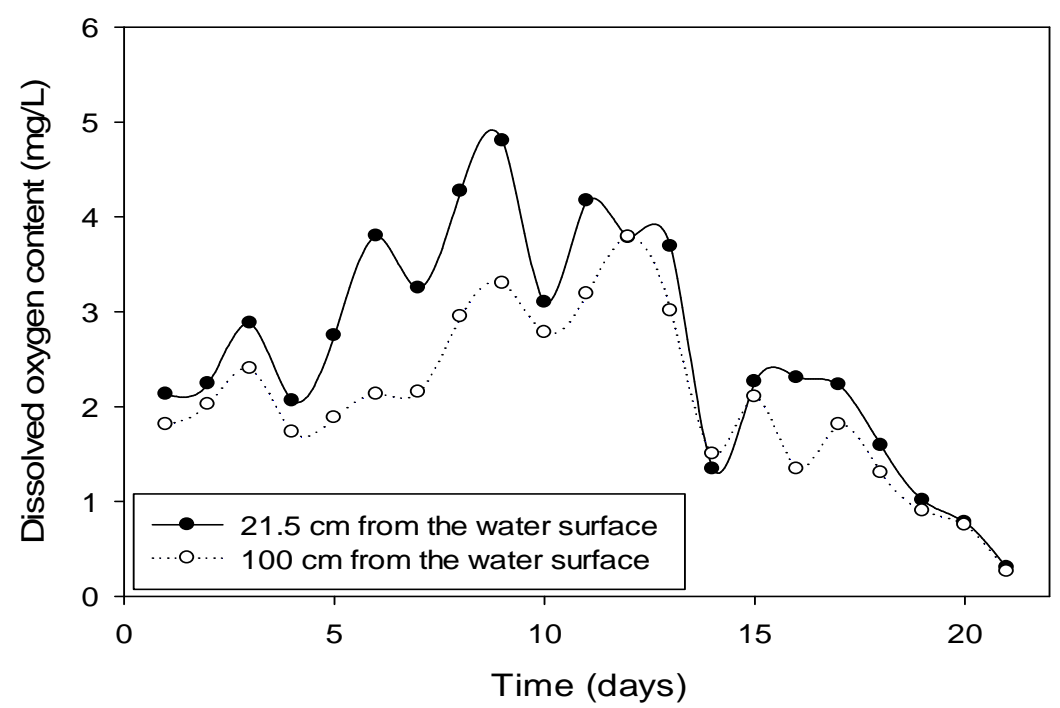

Figure 4: Variation in the oxygen content in the filter placed near the clarifier.

Table 1: Removal efficiency and average characteristics of filtered wastewater sampled after 1.5 days of settling.

\begin{tabular}{llcccc}
\hline & & \multicolumn{3}{c}{ Levels } \\
\cline { 3 - 6 } & & Inlet & Level 1 & Level 3 & Outlet \\
\hline \multirow{4}{*}{ TSS } & Min (mg/l) & 41 & 38 & 21 & 4 \\
& Max (mg/l) & 90 & 65 & 58 & 59 \\
& Average (mg/l) & 65 & 48 & 33 & 22 \\
& Removal (\%) & & 26 & 49 & 66 \\
\hline \multirow{4}{*}{ COD } & Min (mg/l) & 753 & 268 & 217 & 163 \\
& Max (mg/l) & 1018 & 574 & 433 & 424 \\
& Average (mg/l) & 910 & 412 & 289 & 243 \\
& Removal (\%) & & 55 & 68 & 73 \\
\hline \multirow{3}{*}{ BOD 5} & Min (mg/l) & 340 & 180 & 140 & 35 \\
& Max (mg/l) & 500 & 180 & 200 & 60 \\
& Average (mg/l) & 420 & 180 & 170 & 47 \\
& Removal (\%) & & 57 & 59 & 89 \\
\hline \multirow{3}{*}{ TKN } & Min (mg/l) & 118 & 80 & 76 & 7 \\
& Max (mg/l) & 163 & 103 & 96 & 16 \\
& Average (mg/l) & 141 & 91 & 86 & 12 \\
& Removal (\%) & & 35 & 39 & 91 \\
\hline
\end{tabular}

Min: minimum; Max: maximum; TSS: Total Suspended Solids;

COD: Chemical Oxygen Demand; BOD 5 : Biochemical Oxygen Demand ;

TKN: Total Kjeldahl Nitrogen. 
Table 2: Removal efficiency and average characteristics of filtered wastewater sampled at the level of the primary settling tank.

\begin{tabular}{|c|c|c|c|c|c|}
\hline & & \multicolumn{4}{|c|}{ Levels } \\
\hline & & Inlet & Level 1 & Level 2 & Outlet \\
\hline \multirow{4}{*}{ TSS } & $\operatorname{Min}(\mathrm{mg} / \mathrm{l})$ & 53 & 61 & 38 & 12 \\
\hline & $\operatorname{Max}(m g / l)$ & 244 & 163 & 122 & 89 \\
\hline & Average (mg/l) & 127.4 & 99.4 & 88.6 & 46 \\
\hline & Removal (\%) & & 21.97 & 30.45 & 63.9 \\
\hline \multirow{4}{*}{ COD } & $\operatorname{Min}(\mathrm{mg} / \mathrm{l})$ & 365 & 386 & 301 & 251 \\
\hline & $\operatorname{Max}(m g / l)$ & 1068 & 630 & 698 & 498 \\
\hline & Average (mg/l) & 681.6 & 532.8 & 443.8 & 362 \\
\hline & Removal (\%) & & 21.83 & 34.88 & 46.88 \\
\hline \multirow{4}{*}{$\mathrm{BOD}_{5}$} & $\operatorname{Min}(\mathrm{mg} / \mathrm{l})$ & 200 & 160 & 120 & 80 \\
\hline & Max (mg/l) & 420 & 240 & 220 & 200 \\
\hline & Average (mg/l) & 263 & 194.3 & 173 & 123 \\
\hline & Removal (\%) & & 26.12 & 34.22 & 53.23 \\
\hline \multirow{4}{*}{ TKN } & $\operatorname{Min}(\mathrm{mg} / \mathrm{l})$ & & 108 & 111.34 & 116.40 \\
\hline & $\operatorname{Max}(m g / l)$ & & 212.40 & 194 & 155.30 \\
\hline & Average (mg/l) & & 169.3 & 146.39 & 131.32 \\
\hline & Removal (\%) & & & 13.53 & 22.43 \\
\hline \multirow{4}{*}{ TP } & $\operatorname{Min}(\mathrm{mg} / \mathrm{l})$ & 13.7 & 13.4 & & 11.64 \\
\hline & Max (mg/l) & 32.43 & 34.5 & & 31.42 \\
\hline & Average (mg/l) & 20.19 & 19.17 & & 18.56 \\
\hline & Removal (\%) & & 5 & & 8.07 \\
\hline \multirow{4}{*}{$\begin{array}{l}\text { Faecal } \\
\text { coliforms }\end{array}$} & $\operatorname{Min}(\mathrm{CFU} / 100 \mathrm{ml})$ & $207.10^{3}$ & $80.10^{3}$ & & $110.10^{3}$ \\
\hline & $\operatorname{Max}(\mathrm{CFU} / 100 \mathrm{ml})$ & $456.10^{4}$ & $432.10^{4}$ & & $210.10^{4}$ \\
\hline & Average $(\mathrm{CFU} / 100 \mathrm{ml})$ & $2317.4 .10^{3}$ & $1842.10^{3}$ & & $1015.2 .10^{3}$ \\
\hline & Removal (\%) & & 20.51 & & 56.19 \\
\hline
\end{tabular}

Min: minimum; Max: maximum; TSS: Total Suspended Solids; COD: Chemical Oxygen Demand; BOD $_{5}$ : Biochemical Oxygen Demand; TKN: Total Kjeldahl Nitrogen; TP: Total Phosphorous; CFU: Colony Forming Units 
Table 3: Removal efficiency and average characteristics of filtered wastewater sampled at the level of the clarifier.

\begin{tabular}{|c|c|c|c|c|c|}
\hline & & \multicolumn{4}{|c|}{$\begin{array}{c}\text { Levels } \\
\end{array}$} \\
\hline & & Inlet & Level 1 & Level 2 & Outlet \\
\hline \multirow{4}{*}{ TSS } & $\operatorname{Min}(\mathrm{mg} / \mathrm{L})$ & 13.6 & 7.4 & 6.2 & 2.2 \\
\hline & $\operatorname{Max}(\mathrm{mg} / \mathrm{L})$ & 22.4 & 14 & 9.8 & 8 \\
\hline & Average $(\mathrm{mg} / \mathrm{L})$ & 17.13 & 11.06 & 7.5 & 4.36 \\
\hline & Removal (\%) & & 35.4 & 56.21 & 74.54 \\
\hline \multirow{4}{*}{ COD } & $\operatorname{Min}(\mathrm{mg} / \mathrm{L})$ & 92.8 & 60.4 & 70 & 48.7 \\
\hline & $\operatorname{Max}(m g / L)$ & 147.9 & 131 & 97.7 & 103.7 \\
\hline & Average (mg/L) & 116.81 & 79.26 & 80.01 & 76.11 \\
\hline & Removal (\%) & & 32.14 & 31.50 & 34.84 \\
\hline \multirow{4}{*}{$\mathrm{BOD}_{5}$} & $\operatorname{Min}(\mathrm{mg} / \mathrm{L})$ & 20 & 15 & 15 & 20 \\
\hline & $\operatorname{Max}(m g / L)$ & 40 & 35 & 30 & 35 \\
\hline & Average (mg/L) & 33.33 & 25 & 24.16 & 26.66 \\
\hline & Removal (\%) & & 25 & 27.51 & 20.01 \\
\hline \multirow{4}{*}{ TKN } & $\operatorname{Min}(\mathrm{mg} / \mathrm{L})$ & 79.6 & & 82.9 & 62.3 \\
\hline & $\operatorname{Max}(m g / L)$ & 186 & & 121 & 126 \\
\hline & Average (mg/L) & 119.46 & & 98.43 & 94.21 \\
\hline & Removal (\%) & & & 17.60 & 21.13 \\
\hline \multirow{4}{*}{$\mathrm{TP}$} & $\operatorname{Min}(\mathrm{mg} / \mathrm{L})$ & 3.9 & 3.7 & 5 & 4.2 \\
\hline & $\operatorname{Max}(\mathrm{mg} / \mathrm{L})$ & 11.8 & 9 & 8 & 9 \\
\hline & Average (mg/L) & 7.93 & 6.30 & 6.65 & 6.61 \\
\hline & Removal (\%) & & 27.16 & 21.33 & 22 \\
\hline \multirow{4}{*}{$\begin{array}{l}\text { Faecal } \\
\text { coliforms }\end{array}$} & $\operatorname{Min}(\mathrm{CFU} / 100 \mathrm{~mL})$ & $27.10^{3}$ & $135.10^{3}$ & $9.9 .10^{3}$ & 22.2 .10 \\
\hline & $\operatorname{Max}(\mathrm{CFU} / 100 \mathrm{~mL})$ & $75.10^{4}$ & $54.10^{4}$ & $20.10^{4}$ & $5.5 .10^{4}$ \\
\hline & Average (CFU/100 mL) & $249.10^{3}$ & $248.10^{3}$ & $100.7 .10^{3}$ & $33.10^{3}$ \\
\hline & Removal (\%) & & 0.003 & 59.5 & 77.2 \\
\hline
\end{tabular}

\section{DISCUSSION}

Performances of settling prior to sand filtration

In regards to the performances of settling prior to sand filtration, the $\mathrm{BOD}_{5}$ concentration of pretreated and decanted wastewater was $44 \mathrm{mg} \mathrm{O}_{2} / \mathrm{L}$, the average removal rate was $27 \%$ (Table 1 ). Thus, the total removal efficiency was around $99 \%$ for TSS, $94 \%$ for COD and $97 \%$ for $\mathrm{BOD}_{5}$. These higher percentages rate of reduction obtained compared with that obtained in Experiment 1 were due to the fact that the filtered wastewaters were more concentrated. The short settling time of 1.5 days did not reduce more most of the pollutants as in Experiment 1 with a longer settling time (12 days). However, the levels of total removal rates obtained, $97 \%, 84 \%, 96 \%$, and $92 \%$ for TSS, $\mathrm{COD}, \mathrm{BOD}_{5}$ and TKN, respectively were as high as in experiment 2. These high efficiencies, independently to the settling 
duration might be due to the ability of the filter media to remove the solids matters from the sludge (Kuffour et al., 2009). As reported by the literature, in the early stages, the main removal process might be due to physical filtration by the substrate due to the high proportion of particulate elements (Rousseau et al., 2004; Wang et al., 2009). On the other hand, the long decanting time did not affect the rate of depollution, because the levels of pollutants removal were close for all parameters. However, twelve days of settling have led to relatively long filtration cycle of 139 days against relatively short time of filtration of about 25 days obtained after 1.5 days of settling. This may be related to blockage of the filter pores by the TSS that had not decanted due to the short period of settling as discussed by Nakayama et al. (2007). These authors have stated that suspended materials trapped by the filter decrease the water flow rate across the filter. Then they advise that the sand media filter must be cleaned by backwashing.

These results have shown that this sand is suited for slow sand filtration after long period of settling. Largely durations of slow sand filters operations without clogging have been reported in the literature. Indeed, Rogers et al. (2011) had operated with beds for 274 and 190 days without clogging. However, it should be noted that they had worked with sand filters with depths of $0.3 \mathrm{~mm}$ and $0.4 \mathrm{~m}$ respectively.

The evaluation of the filtration efficiency showed that the variation of head losses at the different levels 3, 4, 5, 6 evolved in the same manner as the level 2 . The head loss rose from $17 \mathrm{~cm}$ water to $55 \mathrm{~cm}$ water in 120 days and from $7 \mathrm{~cm}$ water to $64 \mathrm{~cm}$ in less than two weeks. In the last week of the experiment, the head loss rose by tenfold, and
$64 \mathrm{~cm}$ water head loss was observed approximately one week later.

For the changes in oxygen content during the filtration (Figure 2), according to Trad Rais and Xanthoulis (1999), and Barbu et al. (2011), whatever the used technology, a crucial issue in the case of aerobic wastewater treatment processes is the control of the dissolved oxygen concentration. For these authors, ensuring a satisfactory level of dissolved oxygen allows the normal development of the microbial wastewater treatment processes. However, the concentration of dissolved oxygen was less than $1 \mathrm{mg} / \mathrm{L}$. These small amounts of oxygen content could result in the quality of the wastewater that was highly loaded in TSS. This can explain the low removal rates of COD, BOD5, TKN and TP recorded in the filter close to the primary settling tank. According to the layer depth the amount of oxygen in the porous media was less important at $100 \mathrm{~cm}$ than at $21.5 \mathrm{~cm}$ (Figure 3 ). The higher amounts of oxygen content at $21.5 \mathrm{~cm}$ could result from gas exchange between the atmosphere and the water surface. Indeed, feeding periods allow oxygen in the water body to be renewed through convection and molecular diffusion (Guilloteau et al., 1993; Mottier et al., 2000). At $100 \mathrm{~cm}$ photosynthetic activity and oxygen consumption in favor of the treatment are more important than exchanges between atmospheric oxygen and the environment (Figure 4).

The differences in oxygen content between the filter close to the primary settling tank and the clarifier, could explain the quality of the effluent in terms of COD, $\mathrm{BOD}_{5}, \mathrm{TKN}$ and TP. According to Bancolé (2002) and $\mathrm{Xu}$ et al. (2012), the oxygen required to oxidize dissolved organic matter and nitrogen is available in the porous 
medium. Oxygen is supplied to the air phase by exchanges with the atmosphere through the bed surface. Two mechanisms are mainly involved in oxygen renewal: convection and molecular diffusion.

Regarding the results of the filtration of the effluent of the primary settling tank and the clarifier (Experiment 3). At the level of the primary settling tank (Table 2), the results show that sand filtration was less effective in removing pollutants from settled wastewater than in Experiments 1 and 2 with pretreated wastewater. These low levels of pollution may be linked to the fact that these wastewaters are less concentrated than those treated in Experiments 1 and 2. Compared to the pretreated wastewater, high removals were observed. Total removals rate were about $92.79,81.13,88.64,12.25,19.30$ and $91.81 \%$ for TSS, COD, $\mathrm{BOD}_{5}$, nitrogen, phosphorus and coliforms. As observed above, pollutants removal was dependent on the depth of the sand filter bed and was increasing from sand surface with the depth. For all parameters, the rate of depollution increases with the depth of the sand layer. Thus, these values are above the permitted limits of 100-200, 40-80, 30, 10 $\mathrm{mg} / \mathrm{L}$ and $2000 \mathrm{CFU} / 100 \mathrm{~mL}$, respectively for COD, BOD5, the TKN, TP and fecal coliforms defined by Senegalese standard NS 05-061 relating to wastewater discharge into the environment. Only TSS with an average concentration of $46 \mathrm{mg} / \mathrm{L}$ seems to conform to this standard that defines a limit value of 40$80 \mathrm{mg} / \mathrm{L}$. As shown by the results, slow sand filtration is not very effective for the removal of wastewater pollution indicators from the primary settling.

For the filter placed close to the secondary settling tank filter (Experiment IV), the results shown by sand filtration of the clarified wastewater are represented in Table 3. According to Haely et al. (2011), the degree to which nutrients are deposited in a filter media depends on the applied organic loading rate. Compared to the pretreated wastewater, the average removal efficiencies achieved were 99.5, 95.55, 98.35, 57.56, 73.56 and $99.73 \%$ on for respectively TSS, COD, BOD5, TKN, TP and faecal coliforms.

Moreover, except for TSS and fecal coliform the levels of depollution for the other parameters are not influenced by the depth of the sand layer. The results of Table 3 show that the rate of removals for $\mathrm{COD}, \mathrm{BOD}_{5}$, TKN and TP are similar whatever the depth of the sand layer. However, the effectiveness of sand filters in removing pollutants has been reported by some authors in the literature. Thus, with coarser sands, an increased sand bed depth can contribute to better filtration. For some authors, the ideal depth is 0.40-0.70 $\mathrm{m}$. It is generally accepted that bacteriological treatment efficiency is more sensitive to depth with sand of large size. But Bellamy et al. (1985) suggested that sand height could be reduced to $0.48 \mathrm{~m}$ with no change in bacteriological removal efficiency. However, ASCE (1991) and Muhammad et al. (1996) concluded that most of the bacteriological purification occurs within the top $0.40 \mathrm{~m}$ of the sand bed. Research done by Loga et al. (2001) on intermittent sand filter columns of $0.60 \mathrm{~m}$ sand revealed that the depth of sand was also important in removal, and became more important for coarser sands. Concerning the effect of sand depth on the removal of nitrogenous organic compounds, the research done by Muhammad et al. (1996), showed that the biochemical oxidation of nitrogenous organic compounds was found to be dependent on sufficient sand bed depth. Thus, the increased sand bed depth $(0.7 \mathrm{~m})$ allowed the full bacterial activity in the filter bed and produces the desired quality of water (BioSandFilter.org., 2004). Also, the reports 
showed that in slow sand filtration, the vertical height of the sand bed that the water has to pass through is important in terms of filtration efficiency. The low removal of the pollutants regardless of the depth of the sand layer may be related to their low concentration in the clarified water. Thus, for TSS, the main removal process was physical filtration by the substrate, due to the high proportion of particulate elements (Rousseau et al., 2004; Wang et al., 2009). Faecal coliforms are essentially eliminated under sedimentation, Brownian diffusion and adsorption (Schmitt, 1989; Gnagne, 1996). These removals are highly dependent on the size of the pollutants, and the meshes and depth of the filter media. Trad Rais and Xanthoulis (1999) showed that the decontamination of effluents is not only determined by the depth of the water column, but also by the temperature. Indeed for depth less than $1.50 \mathrm{~m}$, faecal coliform reduction of about $3 \log$ units is observed within 8 days, when the temperature varies between 25.5 and $28{ }^{\circ} \mathrm{C}$ and when it is below $20{ }^{\circ} \mathrm{C}$, the decontamination of water is considerably slowed. When the water temperature is between 12.5 and $18{ }^{\circ} \mathrm{C}$, the reduction of fecal coliforms is only $3 \mathrm{log}$ units after 17 days. Cleasby et al. (1984) have reported average percentages of coliforms removal over $99 \%$ using an effective sand size of $0.32 \mathrm{~mm}$ and sand depth of $0.94 \mathrm{~m}$. The high coliforms removal efficiency achieved by slow sand filter is partly explained by the slow filtration rate and fine effective size of the sand, but is also attributed to biological processes in the layer of slime material that accumulates above the sand surface (schmutzdecke) and within the upper layers of the sand bed (Tyagi et al., 2009). The significant reduction in nitrogen and phosphorus suggests according to Kavanaugh et al. (1977) that these nutrients particularly phosphorus have been heavily used during the filtration cycle.

Except for the faecal coliforms concentration, the sand flow filter beds produce filtered wastewater effluent meeting Senegalese standards (ISN, 2001). Thus, slow sand filtration can be a valuable technology for clarified wastewater processing for elimination into the environment or other uses.

\section{Conclusions}

This study of slow sand filtration for wastewater in tropical environment was performed, particularly in Senegal. It appears from the results that the experimental devices contributed to reduce the overall wastewater pollution slightly. Long settling period is important to maintain the efficiency of the system. Therefore, in such conditions, it is not an appropriate method for the treatment of wastewater highly concentrated in various pollutants. In this context, the success of such a technology will depend on external conditions, which take into account the design and operation of the filtration device. The use of such a processing device may be advantageous as a finishing treatment of wastewater for agricultural purposes in the tropical regions. Therefore, due to excellent effluent quality from the filter treating clarified wastewater, it can be said that slow sand filtration could be a promising technology for the post treatment of digested effluent in developing countries, where treated effluent can be reused for various recreational purposes i.e. gardening and irrigation, as well as for safe discharge

\section{REFERENCES}

Abdel Ghaffar E. 2007. Wastewater natural treatment using multi-criteria decision analysis technique. $11^{\text {th }}$ International 
water technology conference, Sharm ElSheikh, Egypte.

Adeniran AE, Akanmu JO. 2013. The Efficiency of Slow Sand Filters in the Treatment of Secondary Effluent from a Water Hyacinth Domestic Sewage Plan. NSE Technical Transactions, 47(2). Available online at : www.academia. edu/.../Slow_Sand_Filter_for_Sewage.

Adin A, Rebhun M.1977. A model to predict concentrations and head-loss profiles in filtration. Jour. $A W W A, \mathbf{8}$ : 444-451.

Adin A, Gerstel Z, Tal NI. 1998. Slow granular filtration for advanced wastewater treatment: Design, Performance and Operation. Final Scientific Report. The Hebrew University of Jerusalem.

Amin HM, Mohamed AA. 2014. Effect of some parameters on performance of direct high-rate filtration in water treatment. Journal of Engineering Sciences Assiut University Faculty of Engineering, 42(3): 609-628

Aomar J, Aomar KAJ, Abdelmajid K. 2002. Réutilisation des eaux usées au Maroc. Forum sur la gestion de la demande en eau. Direction du développement et de la gestion d'irrigation. Ministère de l'agriculture, du développement rural et des eaux et forets. http://www.idrc.ca/ uploads/user-S/10637175471Maroc.doc

ASCE. 1991. Slow sand Filtration. Logsdon GS (ed). American Society of Civil Engineers: New York, USA.

Bancolé A, Brissaud F, Gnagne T. 2002. Oxidation processes and clogging in intermittent unsaturated infiltration $5^{\text {th }}$ Specialized Conference on Small Water and Wastewater Treatment Systems, Istanbul, 24-26 Sept 2002. 1, 235-242.

Barbu M, Caraman S, Bahrim G, Carp D. 2011. Results regarding the control of the dissolved oxygen concentration in wastewater treatment processes. Romanian Biotechnological Letters, 16(2): 6097.

Bastian RK. 2013. 2012 EPA guidelines for water reuse. Available online at: http://www.epa.gov/nrmrl/publications.h tml

Bellamy WD, Hendricks DW, Longsdon G.S. 1985. Slow Sand Filtration: Influences of Selected Process Variables. American Water Works Association Journal, 77 (12): 62-66.

BioSandFilter.org. 2004. Sand as a filter media. Available online at : http://www. biosandfilter.org/biosandfilter/index.php/ item/289

Channing RC, Chu T, Wang KH. 2007. Study of the Head Loss Associated with a Fluid Flowing through a Porous Screen. Final Report. Available online at: http://www.rsmsl-1.me.uh.edu/.../ REU_ Channing_Santiago_Final.

Cleasby JL, Hilmoe DJ, Dimitracpoulos CJ. 1984. Slow sand and direct in-line filtration of a surface water. J. Am. Water Works Assoc., 76(12) 44-54.

Dash RR, Dash RR, Verma AK, Bhunia P. 2012. Sand filtration: An effective post treatment option for aerobically treated wastewater. J. Ind. Res. \& Technology 2(2): 81-87.

Eaton AD, APHA, AWWA, WEF. 2005. Standard Methods for the Examination of Water and Wastewater (21 $1^{\text {st }}$ edn). APHA-AWWA-WEF: Washington D.C.

Gnagne T. 1996. Épuration par infiltration d'eaux usées à forte charge organique en milieu tropical. Thèse de Doctorat en Sciences de l'Eau dans l'Environnement Continental. Université de Montpellier II, France. 
Guilloteau JA, Lesavre J, Lienard A, Genty P. 1993. Wastewater treatment over sand columns. Treatment yields, localisation of the biomass and gaz renewal. 2nd international specialized conference on design and operation of small wastewater treatment plants, Trondheim, Nordway, 28-30 June. 153-160.

Healy MG, Rodgers M, Burke P. 2011. Quantification of biofilm build-up in filters when intermittently loaded with low-strength synthetic wastewater. Desalination, 271: 105-110.

ISN (Institut sénégalais de Normalisation). 2001. Eaux usées : Normes de rejet. NS 05-061.

Kavanaugh M, Sigster K, Weber A, Boiler M. 1977. Contact filtration for phosphorus removal. J. Water Pollut. Control Fed., 49: 2157.

Kuffour AR, Awuah E, Anyemedu FOK, Strauss M, Koné D, Cofie O. 2009. Effect of using different particle sizes of sand as filter media for dewatering faecal sludge. Desalination, 248(1-3): 308-314.

Logan AJ, Stevik TK, Siegrist RL, Rønn RN. 2001. Transport and fate of Cryptosporidium parvum oocysts in intermittent sand filters. Wat. Res., 35: 18: 4359-4369.

Mbaye A, Diop C, Matty F, Sarr D, Cisse L, Isselmou OH, Da Silva A, Mbaye M, Tine A. 2012. Evaluation de la performance du filtre lent à sable en élimination de quelques pesticides (Diuron, Maneb, Carbofuran) présents dans les eaux usées par spectrophotométrie UV-visible. J. Soc. Ouest-Afr. Chim., 034: 19- 25.

Mottier V, Brissaud F, Nieto P, Alamy Z. 2000. Wastewater treatment by infiltration percolation : a case study.
Water Science and Technology, 41(1). 77-84.

Muhammad N, Ellis K, Parr J, Smith MD. 1996. Optimization of slow sand filtration. Reaching the unreached: challenges for the 21st century. 22nd WEDC Conference New Delhi, India, 1996, 283-285.

Nakayama FS, Boman BJ, Pitts DJ. 2007. Maintenance In Microirrigation for Crop Production: Design, Operation, and Management. Developments in Agricultural Engineering (vol 13), Lamm FR, Ayars JE, Nakayama, FS. (eds). Elsevier: Amsterdam; 389-430.

Niang S, Redwood M. 2002. Wastewater Reuse in Dakar, Senegal. Hyderabad workshop November 2002.

Rodgers M, Walsh G, Healy MG. 2011. Different depth intermittent sand filters for laboratory treatment of synthetic wastewater with concentrations close to measured septic tank effluent. Journal of Environmental Science and Health Part A, 46: 80-85.

Rousseau DPL, Vanrolleghem PA, De Pauw N. 2004. Constructed wetlands in Flanders: A performance analysis. Ecological Engineering, 23(3): 151-163.

RSA. 2012. Department of public works. Small waste water treatment works dpw design Guidelines. Available online at: http://www.www.publicworks.gov.za/.../ Design_guidline_for_Sm...

Schmitt A. 1989. Modélisation de l'épuration par infiltration. Thèse de Doctorat, Spécialité Hydrologie, Sciences de 1'Eau et Aménagement, Université de Montpellier II. France.

Shetty S. 2004. Treated wastewater use in Tunisia: lessons learned and the road ahead. In Wastewater Use in Irrigated Agriculture: Confronting the Livelihood 
and Environmental Realities, Scott CA, Faruqui NI, Raschid-Sally L (eds). CABI Publishing: Wallingford; UK ; 163-171.

Trad Raïs M, Xanthoulis D. 1999. Amélioration de la qualité microbiologique des effluents secondaires par stockage en bassins. Bitechnol. Agron. Soc. Environ., 3(3): 149- 157.

Tyagi VK, Khan AA, Kazmi AA, Mehrotra I, Chopra AK. 2009. Slow sand filtration of UASB reactor effluent: A promising post treatment technique. Desalination 249: 571-576.

Wang R, Korboulewsky N, Prudent P, Baldy V, Bonin G. 2009. Can vertical-flow wetland systems treat high concentrated sludge from a food industry? A mesocosm experiment testing three plant species. Ecological Engineering 35(2): 230-237.

WHO (Wold Health Organization). 2006. Guidelines for the safe use of wastewater, excreta and greywater, Volume 2, Wastewater use in agriculture, WHO, 222.

Xu H, Scherrenberg S M, Van Lier JB. 2012. Dissolved oxygen, COD, nitrogen and phosphorus profiles in a continuous sand filter used for WWTP effluent reclamation. Water Science \& Technology, 66(7): 1511-1518. 